\title{
IMPLEMENTASI PENDIDIKAN KARAKTER MELALUI PEMBIASAAN DI PONDOK PESANTREN PABELAN
}

\author{
IMPLEMENTATION OF CHARACTER EDUCATION THROUGH HABITUATION IN ISLAMIC \\ BOARDING SCHOOL OF PABELAN
}

\author{
Nur Hidayat \\ PGMI FITK UIN Sunan Kalijaga Yogyakarta \\ Alamat E-mail bos_hidayat@yahoo.com
}

\begin{abstract}
ABSTRAK
Penelitian ini dilatarbelakangi oleh suatu pengamatan di lapangan bahwa untuk menanamkan pendidikan karakter kepada anak didik ada beberapa proses yang harus diperhatikan oleh seorang pendidik, di antaranya adalah melalui proses pembiasaan. Di sini peneliti mengambil lokasi penelitian di Pondok Pesantren Pabelan dan tinggal selama lima belas hari untuk mengamati kegiatan dan aktifitas santri setiap hari. Untuk implementasi pendidikan karakter melalui pembiasaan tersebut peneliti bersama para santri ikut merasakan apa yang dilakukan kegiatan santri setiap harinya. Diantaranya diperoleh hasil pertama, santri membiasakan Salat fardhu lima waktu secara berjama ah di masjid maupun di asrama. Kedua, santri membiasakan makan tepat waktu, santri membiasakan olah raga pagi hari sehabis Salat shubuh dan pembiasaan-pembiasaan yang lainnya.
\end{abstract}

Kata kunci : Pendidikan karakter, Pembiasaan, dan Pondok Pesantren Pabelan

\section{ABSTRACT}

This research is motivated by an observation field that to instill character education to the students there are several processes that must be considered by an educator, including through a process of habituation. Here, the researchers took the study site in Pondok Pesantren Pabelan and stayed for fifteen days to observe the events and activities of students every day. For the implementation of character education through the habituation of researchers together with the students to feel what the students every day activities. Among the first results obtained, students familiarize obligatory prayers five times a day in berjama ah dimasjid or in a dormitory. Second, the students get used to eating on time, students get used to exercise the morning after the morning prayer and habituation-conditioning the other.

Keywords: character education, habituation, and islamic boarding school of Pabelan

\section{Pendahuluan}

Akhir-akhir ini dunia pendidikan termasuk pendidikan formal, non formal dan informal sedang mengalami ujian dan tantangan yang cukup berat. Tantangan yang dihadapi oleh dunia pendidikan sekarang ini di antaranya, merosotnya nilai-nilai moral, budi pekerti luhur, karakter dan akhlak bagi anak didik. Dampak lain dari merosotnya moral atau akhlak di Indonesia dapat kita saksikan 
(Amiruddin Nahrawi, 2008: 64) berita-berita yang dimuat koran, seperti masalah pergaulan bebas, penyalahgunaan narkoba, tawuran, dan perkelaihan antar pelajar (Kompas, 2001:46) dengan pelajar di kota-kota besar. Di samping itu juga sering kita saksikan akhir-akhir ini pada berita dan tayangan di TV one, 2011 tentang perilaku kriminal, demo besar-besaran dengan mengerahkan massa secara anarkis dari kalangan mahasiswa dan masyarakat yang menuntut penurunan harga BBM sampai terjadi perusakan rumah, (Metro TV, 2014: pukul 20.30 WIB) pembakaran mobil bahkan sampai ada yang meninggal.

Perilaku yang semacam ini sangat bertentangan dengan budaya luhur yang sebelumnya dikenal ramah dan santun menjadi menjadi luntur. Kemudian bila dicermati, yang terjadi sekarang adalah lemahnya sikap toleransi terhadap sesama warga, menurunnya kepercayaan akan kebenaran sistem negara bangsa yang diwariskan oleh pendiri republik dan berbagai tingkah laku moral yang bertentangan dengan norma agama, sosial dan nilai-nilai luhur bangsa kita (Prayitno, 2010 : 24). Lalu banyak kalangan yang akhirnya bertanya, apa yang salah dengan pendidikan nasional kita sehingga belum berhasil membangun karakter bangsa sebagaimana yang diamanatkan Pancasila, UUD 1945 dan UU No. 20 tahun 2003 tentang Sistem Pendidikan Nasional. (Ki Fudyartanta, 2010: 26-27)
Perilaku yang semacam ini merupakan bukti fenomena sosial di masyarakat yang dirasakan semakin memprihatinkan (KR, 2013: 7). Lebih memprihatinkan lagi, fenomena sosial tersebut juga melanda pada anak-anak remaja yang sedang dalam proses perkembangan, pertumbuhan wawasan intelektual dan ilmu pengetahuannya menjadi manusia dewasa harapan bangsa. Mereka yang seharusnya masih membutuhkan pembiasaanpembiasaan yang baik dalam pendidikan sejak dini, pendidikan ilmu pengetahuan dasar agama, pembinaan kepribadian moral, akhlak yang luhur, dan pendampingan serta perlindungan dari orang tua yang semestinya dapat memberikan suri teladan atau contoh yang baik bagi mereka.

Di samping itu, dengan perkembangan teknologi, informasi dan komunikasi yang begitu pesat dan sulit dibendung, akan sangat berpengaruh terhadap pembiasaan dan perubahan karakter akhlak anak bangsa generasi penerus. Di sini, pembiasaan sikap menghargai dan rasa hormat kepada diri sendiri, menghormati kepada orang lain yang lebih tua termasuk didalamnya menghormati kepada orang tua, guru, pendidik, sudah mulai pudar dan berkurang. Kemudian sikap pembiasaan kepedulian dan rasa cinta kepada alam semesta sebagai rasa hormat kepada sang pencipta dan ungkapan syukur atas anugrah yang diberikan oleh Allah Swt kepada kita semua sudah sulit ditemukan oleh bangsa kita. 
Kemampuan untuk mengendalikan diri dan mengatur emosi, prilaku santun yang sesuai dengan tatanan norma dan adat istiadat setempat, sikap toleransi dan cinta damai, perilaku moral yang bertanggungjawab, tampaknya sudah tidak lagi dipandang sebagai nilai-nilai kehidupan yang penting dalam memandu dan mengarahkan kehidupan manusia, baik sebagai makhluk individual maupun makhluk sosial (Ki Fudyartanta, 2010: 1)

Dari beberapa fenomena dan keprihatinan yang terjadi akhir-akhir ini di Indonesia, yaitu tentang pembiasaan yang buruk dan degradasi moral, etika, dan akhlak yang semakin menurun ini, maka masalah ini menjadi tugas dan tanggung jawab kita bersama mulai dari keluarga, masyarakat dan pemerintah untuk segera ditangani dan dicarikan jalan keluarnya. Keprihatinan dan fenomena tersebut oleh mantan Menteri Pendidikan Nasional, Muhammad Nuh ditanggapi dengan serius. Beliau akan mencontoh menerapkan model pendidikan karakter yang ada di pesantren dengan diberlakukan pada sekolah umum. Karena model pendidikan karakter yang dikembangkan oleh pesantren menurut beliau telah berhasil. (Annisa Mutia, 2013: 23) Tujuan transfer pendidikan karakter dari pesantren adalah untuk membentuk budaya sekolah yang dilakukan melalui pembiasaan nilai-nilai positif yang ada di sekolah. Hal senada juga disampaikan oleh mantan Rektor UIN Syarif Hidayatullah, Komaruddin Hidayat memandang perlu adanya transfer pendidikan karakter dari pesantren ke sekolah umum. Karena model pendidikan pesantren lebih menekankan pada pembiasaan-pembiasaan yang baik dan nilai-nilai kultur serta kepribadian yang berbasis pada agama. (Komarudin Hidayat, 2008 : 76). Menurut Hidayat, ada beberapa hal penting yang bisa ditransfer dari sistem model pesantren ke lembaga pendidikan umum, seperti keteladanan, pembiasaan, kepribadian, kepemimpinan, dan kewibawaan. Disini figur pemimpin atau kyai yang mempunyai jiwa keteladanan, maka ia dianggap sebagai modal berharga dalam menanamkan pembiasaan para santri melalui proses belajar mengajar. (Muhaimin, dkk., 2002: 25)

Pembentukan karakter lewat pesantren dimulai dengan pembiasaan-pembiasaan yang positif seperti, pola hidup sederhana, menumbuhkan rasa persaudaraan dan persahabatan yang erat antarsantri sehingga kecil kemungkinan terjadi konflik dan perkelahian. (Zamakhsyari Dhofier, 1982: 55) Krisis moral dan akhlak yang baru melanda di tanah air kita akhir-akhir ini sebenarnya bisa diatasi dengan lembaga pendidikan yang sudah ada yaitu lewat pendidikan pesantren melalui pembiasaan yang positif disegala aspek kehidupan santri. Lembaga pendidikan model pesantren yang ditawarkan oleh peneliti dalam 
penelitian ini adalah "implementasi model pendidikan karakter melalui pembiasaan di pondok pesantren Pabelan”. (M. Amin Haedari, dkk, 2006: 11) Adapun rumusan masalahnya, Pertama, bagaimana implementasi pendidikan karakter melalui pembiasaan di pesantren Pabelan? Kedua, apa faktor pendukung dalam mewujudkan implementasi pendidikan karakter melalui pembiasaan di pesantren Pabelan?

Landasan Teori

Pengertian Pembiasaan. Kemudian, arti pembiasaan atau kebiasaan menurut Kamus Besar Bahasa Indonesia (Tim Penyusun Kamus Pusat Pembinaan dan Pengembangan Bahasa, 2006: 345) adalah pola untuk melakukan tanggapan terhadap situasi tertentu yang dipelajari oleh seorang individu dan yang dilakukannya secara berulang dalam hal yang sama (Tim Penyusun Kamus, 2006: 144). Ada beberapa pengertian yang dikemukakan oleh para ahli diantara pengertian-pengertian kebiasaan adalah : pertama, kebiasaan adalah tingkah laku yang cenderung selalu ditonjolkan oleh individu dalam menghadapi keadaan tertentu atau ketika berada dalam keadaan tertentu (Armai Arief, 12007: 110). Kedua, kebiasaan merupakan proses "Internalisasi" dari norma masyarakat, dan adanya kematangan dari sudut organik biologik yang diwujudkan dalam bentuk perilaku sadar. Ketiga, kebiasaan merupakan hasil dari rangkaian rangsang dan jawaban yang dipelajari oleh anak dan dilakukan secara berkesinambungan. (Abdul Mujib, 2007: 12) Jadi latihan pembiasaan merupakan upaya yang intensif untuk menciptakan lingkungan (rangsang) sebagai sumber dari timbulnya tingkah laku, yang cenderung selalu ditonjolkan oleh individu sebagai proses internalisasi dari norma-norma lingkungan agar diperoleh kematangan dan perkembangan kepribadian yang optimal (M Ngalim Purwanto, 1986: 224). Kebiasaan biasanya dilakukan secara turun temurun dari orang tua ke anak, dari guru ke murid (Muhaimin, dkk, 2002 : 174-175). Sehingga dalam prakteknya kebiasaan buruk pun akan dianggap benar karena sudah tertanam dalam alam bawah sadar manusia. Pembiasaan agar menjadi kebiasaan dimulai sejak usia dini. Bahkan sejak dalam kandungan janin atau bayi sudah diperdengarkan murathal al-quran maupun musik mozart untuk perkembangan otaknya. Demikian pula halnya dengan kesehatan (Thomas Lickona, 2012: 23).

Di negara maju, kebiasaan ini telah menjadi budaya, bahkan sampai etika di kamar kecil dan lainnya. Seharusnya di negara yang mayoritas penduduknya memeluk agama Islam hal ini bukan barang baru lagi, karena telah diajarkan beristinja, berwudhu, tayamum, bersiwak dan mandi. Sehingga kebersihan dan kesehatan melekat dalam kehidupan seharihari. Tetapi semua ini tidak sejalan di Negara kita. Hal inilah yang menyebabkan banyak penyakit di Indonesia berbasis lingkungan dan 
perilaku hidup tidak bersih dan sehat. Di samping itu, ada beberapa Pengertian kebiasaan belajar menurut pada ahli juga berbeda-beda, tergantung dari sudut mana ahli tersebut mendeskripsikan kebiasan belajar. Kebiasaan belajar adalah perilaku belajar seseorang dari waktu ke waktu dengan cara yang sama, dalam rangka menambah ilmu pengetahuan baik disekolah maupun di rumah (Hasan Langgulung, 1991: 34). Kebiasaan belajar yang bersifat positif atau baik akan membantu siswa untuk menguasai materi pelajaran, sehingga dengan memiliki kebiasaan belajar yang baik maka seseorang akan menentukan keberhasilan di dalam belajarnya.

Dalam Kamus Besar Bahasa Indonesia pengertian kebiasaan adalah sebagai sesuatu yang biasa dikerjakan(M. Athiyah al-Abrasyi, 1990: 46). Pengertian kebiasaan belajar merupakan cara bertindak yang diperoleh melalui belajar secara berulang-ulang, yang pada akhirnya menjadi menetap dan bersifat otomatis. Sedangkan menurut Sulaeman kebiasaan belajar dapat diartikan sebagai caracara atau teknik-teknik yang mantap yang dilakukan siswa pada waktu ia menerima pelajaran dari guru, membaca buku dan mengerjakan tugas-tugas sekolah, serta pengaturan waktu untuk menyelesaikan kegiatan-kegiatan tersebut. Oemar Hamalik (2005) mengemukakan "seseorang yang ingin berhasil dalam belajar hendaknya mempunyai sikap serta kebiasaan belajar yang baik."
Dari beberapa pengertian belajar di atas dapat diambil kesimpulan bahwa kebiasaan belajar adalah cara-cara yang ditempuh siswa dalam belajar untuk mencapai tujuan tertentu yang dilaksanakan secara rutin sehingga menjadi suatu kebiasaan. Sedangkan menurut Gilmer menyebutkan bahwa "Habit a well learned response carried out outomatically". (Hasbullah, 1996: 67) Jadi kebiasaan memiliki kekuatan untuk mendominasi tingkah laku seseorang. Dari pengertian tersebut dapat disimpulkan beberapa hal sebagai berikut: pertama, Kebiasaan adalah hasil belajar yang menunjukan pola perilaku tertentu. Kedua, kebiasaan selalu memunjukan suatu perilaku. Ketiga, Kebiasaan memiliki sifat atau corak seperti: konsisten, otomatis, pasti, mudah, terintegrasi dengan pribadi individu. Kebiasaan juga bisa kuat atau lemah tergantung motivasi yang mengiringinya dari maksud dan tujuan kegiatan yang telah menjadi kebiasaan itu. Keempat, Kebiasaan belajar yang tersusun dan terencana dengan baik akan menghasilkan suatu prestasi yang dapat memberikan dorongan bagi diri individu untuk terus berprestasi (Abdullah Nashih Ulwan, 1991: 59).

Dasar Teori Pembiasaan. Sudah sejak lama para ilmuwan dan ahli pikir memperhatikan seluk beluk kehidupan anak, khususnya dari sudut perkembangannya, untuk menuju proses kedewasaan (Hamdani Ali, 1990: 46). Anak harus tumbuh dan 
berkembang menjadi manusia matang, yang sanggup dan mampu mengubah dirinya sendiri, mandiri, tidak tergantung kepada orang lain. Bahkan tidak menimbulkan masalah bagi keluarga, kelompok dan masyarakatnya (Alwisol, 2009: 66). Pada akhir abad 17 seorang filsuf Inggris bernama John Locke mengemukakan bahwa faktor pengalaman dan pendidikan merupakan faktor yang paling menentukan dalam perkembangan kepribadian anak. Anak digambarkan secarik kertas yang masih bersih. Jadi coretan yang meninggalkan jejak kertas itu, menentukan bagaimana kertas itu jadinya. John Locke memperkenalkan teori tabula rasa yang mengungkapkan pentingnya pengaruh pengalaman dan lingkungan hidup terhadap perkembangan anak. Ketika dilahirkan seorang anak adalah pribadi yang masih bersih dan peka terhadap rangsangrangsang yang terjadi di lingkungan orang tua dan keluarga yang menjadi lingkungan terdekat. (Yunahar Ilyas, 2007: 44).

Babak menjadi tokoh penting dalam mengisi secarik kertas yang bersih itu. Pandangan John Locke dikenal dengan teori empirisme (pengalaman) atau teori Environment (lingkungan). Seorang filosof lain bernama Jean Jacques Rousseau mengemukakan pandangan terhadap perkembangan anak yang berbeda dengan John Locke. J.J. Rosseau berpendapat, bahwa seorang anak ketika dilahirkan sudah mempunyai dasar-dasar kepribadian/moral yang baik. Anak mempunyai potensi dalam dirinya yang dibawanya sejak lahir. Pandangan Rosseau menjadi titik tolak dari pandangan yang menitik beratkan faktor dunia dalam atau faktor keturunan sebagai faktor yang penting terhadap isi kejiwaan dan gambaran kepribadian seseorang. Karakteristik yang diperlihatkan seseorang bersifat instrinsik (munculnya dari dalam diri seseorang ) pandangan Rosseau ini terkenal dengan istilah nativisme (Hasan Langgulung, 1992: 88). Kedua pandangan diatas dengan saling bertolak belakang menjadi obyek pembahasaan ahli-ahli psikologi dan ahli pendidikan dengan rentang waktu relatif lama dan belum ada penyelesaian yang memuaskan semua pihak. Akhirnya pada tahun 1958 seorang psikolog wanita yang pernah menjadi presiden asosiasi psikologi Amerika bernama Anne Anastasi, mengemukakan pendapat yang mendekatkan pandangan Enpirisme dengan Nativisme. Yang sedikit banyak, telah meredakan kedua sudut pandang tersebut (Mulyasa, 2007: 76). Anastasi mengemukakan bahwa, pengaruh keturunan (Nativisme) terhadap perkembangan kepribadian perkembangan seseorang selalu terjadi secara tidak langsung, tidak satupun fungsi-fungsi psikis seseorang yang secara langsung di turunkan oleh orang tuanya, pengaruh keturunan selalu membutuhkan perantara atau perangsang yang terdapat dalam linkungan, sekalipun kenyataanya memang ada semacam tingkatan yang lebih atau kurang. 
Hal itu bisa di lihat dengan kenyataankenyataan sebagai berikut : Pertama, latar belakang keturunan yang sama, mungkin dihasilkan ciri-ciri kepribadian yang beda pada kondisi-kondisi lingkungan yang berbeda pula. Kedua, latar belakang keturunan yang berbeda dan lingkungan hidup yang berbeda pula, dapat dihasilkan pola perkembangan yang sama atau hampir sama. (Koesoema A, 2007: 38). Ketiga, lingkungan hidup yang sama bisa menimbulkan perbedaan-perbedaan ciri kepribadian pada anak-anak yang berlainan latar belakang keturunannya. Keempat, Lingkungan hidup yang tidak sama. Bisa menimbulkan perasaan dalam ciri-ciri kepribadian, meskipun latar belakang keturunan tidak sama.

Mengenai pengaruh lingkungan, Anastasi mengemukakan adanya faktor segmental, yakni ada kalanya berlangsung dalam satuan waktu yang singkat, ada kalanya berlangsung dalam jangka waktu yang lama. Ada masa-masa ketika pengaruh lingkungan yang sangat kecil, dan sebaliknya ada masamasa dimana pengaruh lingkungan yang sangat besar, pada peristiwa traumatis (goncangan jiwa) bisa menjadi contoh ketika terjadi dalam waktu relektif singkat, tapi pengaruhnya bisa sangat lama, atau bahkan menetap dan tidak bisa diperbaiki lagi. (Maimunah, 2009: 69). Mengenai hubungan faktor keturunan dan faktor lingkungan Anastasi mengemukakan: pertama, faktor lingkungan dan faktor konstitusi menjadi sumber dari timbulnya setiap perhubungan tingkah laku. Kedua, faktor ini tidak bisa berfungsi terpisah melainkan saling berubungan.

Kemudian untuk melengkapi data tentang teori ini, peneliti juga menyampaikan teori pembiasaan yang lain. Dan teori ini dapat kita cermati dari sebuah kata mutiara yang sudah biasa dikenal oleh para pakar ahli dalam bidang psikologi pendidikan. Kata-kata hikmah tersebut adalah sebagai berikut ini; pertama, jika anak dibesarkan dengan celaan, ia belajar memaki. Jika anak dibesarkan dengan permusuhan, ia belajar berkelahi. Jika anak dibesarkan dengan ketakutan, ia belajar untuk gelisah. Jika anak dibesarkan dengan penghinaan, ia belajar menyesali diri. Jika anak dibesarkan dengan cemoohan, ia belajar rendah diri. Jika anak dibesarkan dengan dipermalukan, ia belajar merasa bersalah. Kedua, jika anak dibesarkan dengan iri hati, ia belajar kedengkian. Jika anak dibesarkan dengan toleransi, ia belajar menahan diri. Jika anak dibesarkan dengan dorongan, ia belajar percaya diri. Jika anak dibesarkan dengan pujian, ia belajar menghargai. Ketiga, jika anak dibesarkan dengan penerimaan, ia belajar mencintai. Jika anak dibesarkan dengan dukungan, ia belajar menyayangi diri. Jika anak dibesarkan dengan pengakuan, ia belajar mengenali tujuan. Jika anak dibesaarkan dengan rasa berbagi, ia belajar kedermawanan. Keempat, jika anak dibesarkan dengan 
kejujuran dan keterbukaan, ia belajar kebenaran dan keadilan. Jika anak dibesarkan dengan rasa aman, ia belajar menaruh kepercayaan. Jika anak dibesarkan dengan persahabatan, ia belajar menemukan cinta dan kehidupan. Jika anak dibesarkan dengan ketentraman, ia belajar berdamai dengan pikiran. (Sumber dari Dorothy Low Notle).

\section{Metode Penelitian}

Penelitian ini adalah penelitian lapangan di Pondok Pesantren Pabelan Magelang Jawa Tengah. Metode penelitian yang digunakan adalah penelitian kualitatif studi kasus (case study). (Patricia A Hays, 2004: 2018) menjelaskan bahwa studi kasus merupakan metode penelitian kualitatif untuk menyelidiki manusia, topik, isu, atau program yang isi dan cirinya unik dalam waktu yang relatif pendek, yakni beberapa pekan sampai satu tahun. Studi kasus ini dilakukan untuk menjawab pertanyaan-pertanyaan yang terfokus dengan membuat deskripsi dan tafsiran yang mendalam.

Selanjutnya, penelitian ini menggunakan pendekatan psikofenomenologi dan teori tipologi dalam kajian antropologi. Studi kasus yang digunakan adalah studi kasus prospektif. Noeng Muhadjir mengatakan bahwa studi kasus prospektif dapat digunakan untuk keperluan penelitian, mencari kesimpulan, dan diharapkan dapat ditemukan pola, kecenderungan, dan arah yang dapat digunakan untuk membuat perkiraan-perkiraan perkembangan ke depan (Noeng Muhadjir ,2002: 79).

Pengumpulan data dalam penelitian ini menggunakan beberapa metode. Pertama, observasi (Zainal Arifin, 2011: 231). Dalam melakukan observasi, peneliti berusaha mengamati secara langsung di lapangan yaitu aktifitas para santri di pondok pesantren Pabelan. Kedua, wawancara. Penelitian ini menggunakan wawancara langsung yaitu wawancara yang dilakukan secara langsung antara pewawancara (interviewer) dan orang yang diwawancarai (interviewee) tanpa melalui perantara. Caranya dengan mewawancarai langsung aktifitas para santri di pondok pesantren Pabelan secara acak. Wawancara dilakukan untuk mendapatkan data tentang bagaimana pendapat dan respon langsung dari para santri di pondok pesantren Pabelan tentang pembiasaan-pembiasaan para santri setiap hari di pesantren secara acak. Ketiga, dokumentasi, adalah teknik untuk mempelajari dan menganalisis bahan-bahan tertulis yang ada di Pondok Pesantren Pabelan. Kemudian datadata lain yang menunjang termasuk buku buku dan arsip penting lainnya yang dapat digunakan untuk mendukung penelitian ini (Moloeng Lexy J, 2005: 241).

\section{HASIL PENELITIAN DAN PEMBAHASAN}

Pembiasaan merupakan upaya praktis dalam pembinaan dan pembentukan karakter 
atau akhlak peserta didik atau siswa. Upaya pembiasaan dilakukan mengingat manusia mempunyai sifat lupa dan lemah. Pembiasaan sebenarnya berintikan pengalaman apa yang dibiasakan. Pada dasarnya yang dibiasakan itu sesuatu yang diamalkan dan pada hakekatnya mengandung nilai kebaikan dan arah yang positif. Oleh karena itu, uraian tentang pembiasaan selalu sejalan dengan mengamalkan kebaikan yang telah diketahui (Haidar Putra Daulay, 2001: 65).

Inti dari pembiasaan dalam pendidikan adalah pengulangan. Misalnya pendidik senantiasa mengingatkan pada peserta didik atau siswa dalam hal berpakaian seorang muslim sebaiknya sesuai dengan tuntunan agama, dan mendapat pahala yang mengikutinya serta mendapat ganjaran atau sanksi bagi yang mengabaikannya. Penyampaian semacam ini apabila didengar dan dipahami, maka dengan sendirinya peserta didik dapat membiasakan diri berpakaian yang sesuai dengan tuntunan agama. Pembiasaan akhlak dimulai sejak anak lahir dengan perlakuan orang tua yang sesuai dengan pembinaan terhadap anak tersebut. Dilanjutkan dengan membiasakan anak melakukan sopan santun yang baik dan budi pekerti luhur yang sesuai dengan agama, serta mendidiknya agar meninggalkan yang tercela dan terlarang dalam agama. Pembiasaan adalah sesuatu hal yang penting dalam pendidikan terutama membiasakan diri dalam berbuat kebaikan dan menanamkan nilai-nilai kebenaran pada diri siswa atau santri. Pendidikan merupakan proses pengubah tingkah laku anak didik agar menjadi manusia dewasa yang mampu hidup mandiri dan sebagai anggota masyarakat dalam lingkungan alam sekitar dimana individu itu berada. Keteladanan seorang guru mencerminkan bahwa segala tingkah lakunya, tutur kata, sifat, maupun cara berpakaian semuanya dapat diteladani.

Di sini, peneliti juga menyempatkan diri melakukan wawancara masalah pembiasaan-pembiasaan yang ada di pondok Pabelan dengan bapak KH Ahmad Najib Amin (Ahmad Najib Amin, 2013: 6). Di antaranya bagaimana sistem pembelajaran di Pesantren Pabelan secara formal dan informal sejak pak KH. Hamam sampai sekarang seperti apa? Jawaban beliau, "Ya tidak jauh berbeda. Jadi kalau nama kami dapat kita lihat di plang yaitu balai Pendidikan, artinya bukan sekedar pengajaran saja, yang hanya tranfer ilmu tapi juga bagaimana anak-anak itu kita didik, dilatih dan dibiasakan bagaimana menjadi anak yang tanggap, jujur, berani, rajin dan tanggung jawab. Kemudian caranya dengan menerapkan prinsip disiplin yang kita buat bersama untuk membuat anak-anak atau para santri menjadi terbiasa. Dan kebiasaan itu insya Allah akan menjadi watak kedua pada diri anak santri. Kata pak Ahmad Najib, "kalau anak-anak dibiasakan jam sekian mandi, jam sekian ngaji, jam sekian olah raga, dan jam sekian belajar, 
nanti insya Allah anak santri belajar selama 6 tahun kebiasaan yang mereka peroleh dan alami di pondok ketika mereka kembali di masyarakat insya Allah akan menjadi kebiasaan dan watak yang baik".

Demikian tadi proses pembiasaan di pondok Pabelan yang sudah peneliti melakukan wawancara langsung dengan pengasuh pesantren Pabelan. Sedangkan pembiasaan yang dimaksudkan oleh peneliti adalah segala aktifitas dan kegiatan santri yang dilaksanakan dengan terus menerus secara rutin dan kontinyu di pondok Pabelan. Peneliti juga melakukan pengamatan dan observasi langsung di lapangan terhadap aktifitas para santri yang dilakukan pada setiap harinya, seperti aktifitas Salat berjama'ah lima waktu, pola makan setiap hari, pola olah raga, dan kegiatan muhadharah pada malam hari. Adapun Akftifitas dan kegiatan para santri tersebut posisi peneliti ikut tinggal di asrama pondok Pabelan yaitu asrama Kandahar selama lima belas hari lebih agar dapat melihat, mengamati, dan ikut bersama para santri dalam kegiatan tersebut setiap harinya. Untuk menjelaskan kegiatan dan aktifitas para santri tersebut akan peneliti sampaikan berikut ini.

Pertama, Pembiasaan Salat bejama`ah para santri. (Pengamatan langsung, 2013). Kegiatan Salat berjama`ah bagi para santri di pondok Pabelan berlangsung secara rutin setiap harinya. Peneliti melakukan pengamatan langsung di pondok Pabelan tentang aktifitas
Salat berjama`ah bagi para santri. "Ada dua tempat untuk melaksanakan Salat berjama`ah bagi para santri, yaitu pertama di masjid Pondok dan tempat yang kedua di asrama santri. Pertama, untuk Salat berjama`ah di masjid sudah ditentukan waktunya, yaitu setiap Salat Maghrib, Salat Subuh dan Salat Dhuhur yang wajib bagi para santri mengikutinya. Kedua, Salat berjama'ah di asrama santri diwajibkan pada waktu Salat Isya', dan Salat Ashar".

Peneliti juga mewancarai salah seorang santri yang sekarang sudah kelas satu mau naik kelas dua Madrasah Tsanawiyah. Berikut peneliti melakukan wawancara dengan Ali Zulfikar dari Pekalongan 25 januari 2014 ahad jam 12. Siswa kelas satu Madrasah Tsanawiyah di Pabelan sudah krasan dapat mengikuti kegiatan di Pondok Pabelan (wawancara Ali Zulfikar, 2014). Awalnya mengikuti kegiatan di pondok agak berat seperti bangun tudur waktu pagi untuk melaksanakan Salat subuh, dan kegiatan muhadharah akan tetapi lamakelamaan terbiasa dan sekarang dia sudah dapat mengikuti dengan baik dan lancar. Kata dia, awalnya melakukan salat berjama`ah secara rutin memang berat sekali, apalagi kalau Salat Subuh yang harus bangun pagi sekitar jam 04.30 terasa cukup berat. Tapi lamakelamaan kegiatan Salat berjama`ah, baik di masjid maupun di asrama sudah mulai terbiasa dan terasa tidak berat lagi, dan ini berjalan sekitar empat sampai lima bulan untuk dapat 
adaptasi dan menyesuaikan diri dengan peraturan tersebut di pondok Pabelan.

Jadi model dari pembiasaan salat berjama`ah di pondok Pabelan diwajibkan bagi semua santrinya, agar menjadi orang yang tertib dan disiplin waktu di kemudian hari. Model Salat berjama ah semacam ini memang harus dilatih dan dibiasakan setiap hari oleh para santrinya, meskipun pada awalnya nampak berat sekali tapi lama-kelamaan menjadi ringan dan terbiasa melakukannya dengan mudah tanpa harus di perintah oleh para murokib atau pendamping kamar.

Kedua, pembiasaan olah raga para santri (Hasil pengamatan, 2014). Aktifitas olah raga para santri di pondok Pabelan sudah ada ketentuan dan waktunya yang diatur oleh pengurus pondok. Adapun waktu dan tempat kegiatan olah raga tersebut juga sudah diatur sedemikian rupa, sehingga para santri bisa mengikutinya dengan tertib, nyaman dan menyenangkan. Di sini peneliti memberikan contoh waktu olah raga yang dimaksud adalah sehabis Salat Subuh berjama’ah di masjid. Nampak para santri setelah selesai Salat berjama`ah terus ke asrama membaca AlQur`an bersama-sama sekitar 15 menit. Kemudian mereka para santri sehabis membaca Qur`an terus ganti pakaian olah raga untuk mengikuti aktifitas olah raga dihalaman pondok dan tempat-tempat lain yang telah disediakan oleh pihak pengurus OPPP. Mereka para santri melakukan aktifitas olah raga sesuai dengan yang minati dan digemari oleh para santri, seperti bola voly, bola basket dan olah raga yang lainnya.

Mereka para santri berdasarkan hasil observasi peneliti di lokasi memang sudah terbiasa rotin mengikuti aktifitas olah raga pada pagi hari mulai pukul 05.30 sampai pukul 06.15 WIB di halaman pondok dan dilapangan. Jenis kegiatan olah raga cukup beragam, termasuk senam pagi, latihan karate, lari pagi dan olah raga lainnya. Di samping waktu sehabis Salat subuh, ada waktu lain yang digunakan olah raga para santri yaitu sehabis Salat Ashar. Para santri juga memanfaatkan waktu tersebut untuk kegiatan olah raga yang sifatnya ekstra dan dilakukan secara rotin setiap harinya. Peneliti mengamati kegiatan olah raga tersebut secara langsung ketika para santri selesai melaksanakan Salat Subuh di masjid kemudian kembali ke asramanya masing-masing membaca Al-Quran sebentar sekitar 15 menit terus mereka ganti pakaian menuju ke lapangan pondok dan dikoordinir oleh pendamping kamarnya serta para murokibnya masing-masing. Nampak waktu itu peneliti mengamati di lapangan mereka para santri ada yang lari-lari pagi, ada yang senam pagi, bermain sepak takro, bermain sepak bola, bola basket dan sebagainya.

Adapun hikmah dan pelajaran dari semua aktifitas dan kegiatan olah raga tersebut bagi para santri di pondok Pabelan adalah untuk kesehatan jasmani dan juga kesehatan 
rohani sehingga para santri tetap dalam kondisi yang selalu sehat yang prima. Di samping itu, agar para santri mengikuti kegiatan belajar mengajar di kelas bisa maksimal, selalu segar dan tetap semangat tidak ngantuk atau tidur dikelas. Kelebihan kegiatan olah raga di pondok Pabelan disamping yang telah dipaparkan di atas itu oleh peneliti, kata pak Ahmad Najib adalah untuk menyalurkan emosi para santri sesuai dengan hobby dan bidangnya masing-masing agar mereka tidak mudah emosi dan marah (wawancara pak Ahmad Najib, 2013). Seperti yang peneliti lihat di lapangan olah raga depan gedung madrasah ada yang senam pagi dengan mengeluarkan suara yang keras sekali. Ini terbukti santri yang tadinya mudah emosi suka marah-marah, kemudian setelah mereka terapi dengan rotin melalui olah raga senam atau olah raga yang lain, maka emosi mereka dapat terkendalikan dengan baik.

\section{Ketiga, Model Pembiasaan}

muhadharah para santri. Aktifitas para santri pondok Pabelan di samping mengikuti pelajaran formal di kelas, juga diwajibkan mengikuti kegiatan pelajaran ekstrakurikuler di antaranya adalah muhadharah. Kegiatan muhadharah di pondok Pabelan berlangsung setiap minggunya dua kali, yaitu pada malam senin dan malam Jum`at sehabis Salat Isya` secara berjama`ah diasrama masing-masing. Peneliti mengamati langsung kegiatan muhadharah tersebut yang dilakukan oleh para santri di pondok Pabelan. Adapun waktu dan tempat pelaksanaan kegiatan muhadharah tersebut dapat peneliti laporkan berikut ini: Untuk muhadharah malam Senin para santri menyiapkan diri dengan menggunakan Bahasa Inggris, sedangkan muhadharah malam Jum`at para santri menggunakan bahasa Arab sebagai bahan pidatonya. Kegiatan muhadharah tersebut dilaksanakan secara rutin di ruangan kelas madrasah dan kegiatan tersebut sudah menjadi budaya serta ciri chas santri pondok Pabelan sejak berdirinya sampai sekarang dengan bahasa pengantarnya yaitu Bahasa Arab dan Bahasa Inggris (wawancara bapak Radjasa, 20113).

Setelah peneliti mengamati di lapangan tempat para santri melaksanakan muhadharah nampak santri-santri mengikutinya dengan penuh semangat dan meriah. Mereka yang sedang tampil di depan kelas sekitar 10 menit lamanya disaksikan oleh teman-temannya dan dewan juri kemudian setelah selesai diberikan tepuk tangan yang meriah dengan memukulmukul bangku serta alat musik lainnya yang sudah disediakan. Dengan kegiatan muhadharah tersebut banyak manfaat yang bisa diambil bagi para santri pondok Pabelan.

Manfaat yang bisa diambil bagi para santri pondok Pabelan di antaranya, mereka menjadi terbiasa latihan mental untuk tampil berpidato di muka umum atau forum di samping itu juga untuk mempraktekkan bahasa asing yang mereka kuasai, yaitu bahasa Inggris dan bahasa Arab sebagai alat komunikasi yang 
sudah dipelajari oleh para santri di pondok Pabelan. Berikutnya, sebagai bekal para santri kalau sudah terjun di masyarakat umum sudah tidak minder lagi dan takut kalau ceramah atau pidato di muka umum.

Keempat, Model Pembiasaan membaca Al-Qur`an para santri. Tentang membaca AlQur`an dan keutamaannya tidak diragukan lagi bagi umat Islam. Ada sebuah hadis Buhkari Muslim disebutkan tentang keutamaan membaca Al-Qu`an. Yaitu, "Sebaik-baik kamu sekalian adalah orang yang belajar Al-Qur`an dan mengajarkan Al-Qur'an”. (HR Bukhari Muslim). Hadis tersebut memberikan tawaran dan dorongan bagi umat Islam agar betul-betul mempelajari, mengkaji dan mendalami AlQur`an dan isi kandungannya dengan baik. Karena kalau Al-Qur`an dibaca saja sudah merupakan suatu pahala tersendiri tanpa memahami artinya, apalagi sampai mengkaji dan memahami isi kandungannya bahkan sampai mengamalkan maka pahala akan lebih banyak lagi. Oleh karena itu, aktifitas membaca Al-Qur`an disebuah lembaga pesantren memang sudah tidak asing lagi, artinya sudah menjadi kebiasaan para santri untuk belajar mengaji Al-Qur`an dari tingkat rendah sampai pada tingkat yang lebih tinggi bahkan sampai menghafal Al-Qur`an. Seperti di pondok Krapyak dan pondok-pondok lainnya yang memang lebih memprioritaskan untuk hafalan Al-Qur`an.
Aktifitas para santri membaca AlQur`an di pondok Pabelan sudah ditentukan jadwal waktu dan tempatnya sesuai dengan kegiatan pondok yang ada. Kegiatan membaca Al-Qur`an tersebut dapat berjalan dengan baik dan lancar serta sudah menjadi kebiasaan kegiatan rotin para santri di pondok Pabelan sejak masa KH Hamam Dja`far hingga sekarang ini. Di sini, setelah peneliti mengamati secara langsung dilapangan kegiatan dan aktifitas santri membaca AlQur`an dapat peneliti laporkan berikut ini. Pertama, setiap waktu menjelang Salat maghrib berjama'ah di masjid pondok nampak para santri membaca ayat-ayat suci Al-Qur`an sambil menunggu imam Salat datang di masjid. Hal ini, memang tidak semua santri membaca Al-Qur`an namun sebagian saja di antara para santri yang membaca Qur`an, karena ada yang membaca buku-buku lain seperti pelajaran di madrasah maupun catatan penting yang harus di hafal dan dipahami oleh sebagian santri. Kedua, sehabis Salat berjama`ah di masjid para santri juga membaca Al-Qur`an di asramanya masing-masing yang dipandu dan dibimbing oleh para pendamping dan murakib, dan ada sebagian santri yang datang ketempat rumah ustadz hafidz mengaji Al-Qur’an. Seperti di rumah KH Ahmad Mustafa bersama ibu nyai bagi santri putri, dan ada juga yang datang kerumahnya KH Muhtaram bagi santri khusus putra. Ketiga, sehabis melaksanakan Salat Subuh berjama`ah di masjid, di sini para santri 
kembali ke kamar atau asramanya masingmasing duduk melingkar kemudian membaca Al-Qur`an bersama-sama yang di pandu oleh ustadz pendamping dan morakib”.

Biasanya yang dibaca oleh para santri surat-surat pendek dari Juz Amma selama 15 menit kemudian ditutup terus selesai untuk persiapan olah raga pagi di halaman pondok. Kegiatan membaca Al-Quran di pondok Pabelan tersebut memang sudah menjadi kebiasaan rotin para santri setiap hari dan berjalan dengan lancar, baik dan istiqomah. Di sini, peneliti juga mewancarai salah seorang santri seniornya ketika awal mula masuk pondok Pabelan yaitu saudara Panca asal Bogor Jawa Barat, berikut ini inti dari hasil wawancara dengan mas Panca. Beliau menyampaikan pengalamannya pada awal masuk pondok Pabelan, yaitu ketika saya masuk di sini pondok Pabelan, saya tidak bisa membaca Al-Qur`an sama sekali. Dan saya selalu takut dengan tes dan pelajaran yang berbau arab termasuk membaca al-Qur`an. Akan tetapi, akhirnya saya ketemu dengan ustadz pondok kemudian saya disuruh membaca buku Iqra. Setelah itu, akhirnya saya disuruh belajar buku iqra setiap habis magrib dan subuh sehari dua kali, akhirnya apa yang terjadi pada diri saya, yaitu setelah masa setahun saya dapat khatam Al-Qur`an dan ikut diwisuda dengan teman-temannya yang lain.

Kelima, Model Pembiasaan belajar para santri. Model belajar yang baik dan benar menurut para pakar adalah istikomah dan tekun belajar setiap hari. Orang belajar yang baik dan benar diumpamakan seperti orang yang sedang makan. Jadi orang yang sedang makan harus diperhatikan prinsip disiplin dan rotinitas, serta jangan terlalu kekenyangan. Begitu juga orang belajar juga sama tidak usah terlalu banyak yang dipelajari akan tetapi sedikit tapi rotin atau istikomah dan dilakukan secara terus menerus. Dalam sebuah kata hikmah disebutkan, "bahwa istikomah itu lebih baik dari pada seribu kemulyaan”. Maka dari itu, sebagai seorang santri harus memperhatikan prinsip tersebut yaitu istikomah atau bahasa Jawanya membiasakan diri dengan ajeg (rotin). Untuk aktifitas belajar para santri pondok Pabelan setelah peneliti mengamati dan terjun secara langsung di lapangan dapat digambarkan berikut ini. Yaitu dengan menggunakan model kelompok dan individual. Untuk model belajar kelompok biasanya waktu dan tempat sudah tentukan dari pihak pengurus. "Di sini, para santri belajar secara kelompok diasramanya masing-masing sehabis melaksanakan Salat Isya` berjama`ah sejak pukul 20.00 WIB s/d pukul 22.00 WIB dan didampingi oleh murokib dan ustadz pendamping. Kegiatan belajar kelompok ini berjalan secara rotin atau istikomah setiap malam hari kecuali pada hari libur madrasah. Sedangkan model belajar secara individual di pondok Pabelan bagi para santri yang sudah memasuki kelas atas, yaitu mulai kelas V dan kelas VI diasrama masing- 
masing”. Di samping itu, aktifitas lain belajar para santri di pondok Pabelan meliputi; belajar disiplin menghargai waktu, yaitu waktu Salat berjama`ah lima waktu, waktu tidur yang benar, waktu makan, dan waktu olah raga. Termasuk bagaimana para santri belajar kesederhanaan, belajar kemandirian, dan belajar beretika yang baik dengan sesama orang. Sedangkan faktor pendukung dalam implementasi pendidikan karakter melalui pembiasaan di pondok Pabelan antara lain; Pertama, para santri tinggal diasrama yang terpadu, sehingga mudah terkontrol oleh para pengurus, dan pengasuh pondok atau pimpinan pesantren. Kedua, terpenuhinya sarana dan prasarana untuk kegiatan para santri seperti kegiatan olah raga, lapangan tenis meja, lapangan Volly dan sepak bola. Ketiga, mempunyai visi dan missi yang jelas di pondok pesantren Pabelan. Keempat. Ada rasa tanggung jawab yang tinggi dari para pengelola, pengurus, dan pimpinan pondok pesantren Pabelan untuk benar-benar mendidik dan menanamkan nilai-nilai akhlak atau karakter yang baik kepada para santrinya. Kelima. Adanya tata tertib dan aturan yang jelas bagi para santri untuk dilaksanakan maupun aturan-aturan yang harus ditinggalkan dalam kehidupan setiap harinya.

\section{Simpulan}

Dari hasil penelitian ini tentang pelaksanaan implementasi pendidikan karakter melalui pembiasaan yang di pondok pesantren Pabelan dapat peneliti simpulkan berikut ini. Pertama, Anak-anak santri pondok pesantren pabelan sudah ada Pembiasaan Salat bejama`ah setiap hari lima waktu. Kegiatan Salat berjama'ah tersebut bagi para santri di pondok Pabelan berlangsung secara rotin setiap harinya. Kedua, anak-anak santri Pondok Pabelan juga sudah melaksanakan Pembiasaan olah raga setiap harinya secara rutin. Aktifitas olah raga para santri di pondok Pabelan sudah ada ketentuan dan waktunya yang diatur oleh pengurus pondok. Ketiga, anak-anak santri pondok pabelan sudah melaksanakan Model Pembiasaan muhadharah secara rotin. Aktifitas para santri pondok Pabelan disamping mengikuti pelajaran formal di kelas, juga diwajibkan mengikuti kegiatan pelajaran ekstrakurikuler diantaranya adalah muhadharah. Keempat, anak-anak santri pondok pabelan sudah melaksanakan pembiasaan membaca Al-Qur`an setiap harinya. Tentang membaca Al-Qur’an dan keutamaannya tidak diragukan lagi bagi umat Islam. Kelima, anak-anak santri pondok pabelan sudah melaksanakan pembiasaan belajar secara rutin setiap hari. Model belajar yang baik dan benar menurut para pakar adalah istikomah dan tekun belajar setiap hari.

Adapun faktor pendukung dalam implementasi pendidikan karakter melalui pembiasaan di pondok Pabelan antara lain; Pertama, para santri tinggal diasrama sesuai 
dengan tingkat dan kelasnya masing-masing.

Kedua, terpenuhinya sarana dan prasarana untuk kegiatan belajar mengajar para santri seperti kegiatan olah raga, lapangan tenis meja, lapangan Volly dan sepak bola. Ketiga, mempunyai visi dan missi yang jelas di pondok pesantren Pabelan. Keempat, ada rasa tanggung jawab yang tinggi dari para pengelola, pengurus, dan pimpinan Pondok Pesantren Pabelan untuk benar-benar mendidik dan menanamkan nilai-nilai akhlak atau karakter yang baik kepada para santrinya. Kelima, adanya tata tertib dan aturan yang jelas bagi para santri untuk dilaksanakan maupun aturanaturan yang harus ditinggalkan dalam kehidupan setiap harinya.

\section{Daftar Pustaka}

Ahmad, Zainal Arifin, 2008, “K.H. Hamam Dja far dan Manajemen Pendidikan Berbasis Masyarakat", Ajip Rosidi (Ed.), Kiai Hamam Dja'far dan Pondok Pabelan:Kesaksian Santri, Kerabat, dan Sahabat, Jakarta: Dunia Pustaka Jaya.

al-Abrasyi, M. Athiyah, 1990, Attarbiyah alIslamiyah, Terjmh. H. Bustami A. Gani dkk., Dasar-Dasar Pokok Pendidikan Islam, Jakarta: PT. Bulan Bintang.

Ali, Hamdani, 1990, Filsafat Pendidikan, Yogyakarta: PT. Kota Kembang.

Alwisol, 2009, Psikologi Kepribadian, Malang: UMM Press.

Amin, Ahmad Najib, "Bapak Saya, Kiai Hamam Dja`far”, Ajip Rosidi (Ed.), Kiai Hamam Dja'far dan Pondok Pabelan:Kesaksian Santri, Kerabat, dan Sahabat, Jakarta: Dunia Pustaka Jaya, 2008
An-Nahlawi, Abdurrahman, 1992, Prinsipprinsip dan Metoda Pendidikan Islam dalam Keluarga, di Sekolah dan di Masyarakat, Bandung: $\mathrm{CV}$. DIPONEGORO

Arief, Armai, 2002, Pengantar Ilmu dan Metodologi Pendidikan Islam, Ciputat Pers, Jakarta,

Arifin, H.M. 1995, Kapita Selekta Pendidikan (Islam dan Umum), Jakarta: Bumi Aksara,

Arikunto, Suharsimi, 2010, Manajemen Penelitian, Jakarta: Penerbit Rineka Cipta,

Armai, Arief, 2002, Pengantar Ilmu dan Metodologi Pendidikan Islam, Jakarta:PT Intermasa,

Bruinessen, Martin Van, 1995, Kitab Kuning Pesantren dan Tarekat, Bandung: Mizan,

Busyro, Muhammad, "Kiprah Pak Hamam”, Ajip Rosidi (Ed.), Kiai Hamam Dja'far dan Pondok Pabelan:Kesaksian Santri, Kerabat, dan Sahabat, Jakarta: Dunia Pustaka Jaya, 2008

Daulay, Haidar Putra, 2001, Historisitas dan Eksistensi Pesantren Sekolah dan Madrasah, Yogya: PT Tiara Wacana,

Dharma Kesuma, dkk., 2011, Pendidikan Karakter , Kajian Teori dan Praktek di Sekolah, Bandung: Penerbit : PT Remaja Rosdakarya,

Dhofier, Zamakhsyari, Mei 2011, Kyai Menatap Masa Depan, Makalah disampaikan pada acara Khaul satu Abad KH. Munawwir pendiri Pondok Pesantren Krapyak Yogyakarta.

Dhofier, Zamakhsyari, 1982, Tradisi Pesantren: Studi tentang Pandangan Hidup Kyai, Jakarta: LP3S. 
Hasbullah, 1996, Kapita Selekta Pendidikan Islam, Jakarta: PT. Raja Grafindo Persada.

Hays, Patricia A., 2004, "Case Study Research" dalam Kathleen deMarrais dan Stephen D. Lapan (Ed.), Foundations for Research Methods of Inquiry in Education and the Social Sciences, (Mahwah: Lawrence Erlbaum Associates Publishers)

Hidayat, Nur, 2013, Akhlak Tasawuf, Yogyakarta: Penerbit Ombak.

Huberman, Matthew B Miles, A. Michael, 2009, Analisis Data Kualitatif, Buku Sumber Tentang Metode - Metode Baru, terj. Tjetjep Rohendi Rohidi, Jakarta: PT.UI - Press.

Ilyas, Yunahar, 2007, Kuliah Akhlaq, Yogyakarta: LPPI UMY.

Jalaluddin 'Abdurrahman bin Abi bakr AsSuyuti, Al-Jaami`us Saghiir Fi-Ahaadiisi al-Basyiir an-Nadhiir, Indonesia: Maktabah Daaru Ihya al-Kutub al-Arabiyah, , $t \mathrm{t}$

James P. Spradley, 2007, Metode Etnografi, Terj. Misbah Zulfa Elizabeth, Yogyakarta: Tiara Wacana.

Kata-kata hikmah, Sumber dari Dorothy low notle

Khamim Zarkasih Putro, 20112, Agresivitas Pelajar di Kota Yogyakarta (Studi Kasus di SMA Muhammadiyah 1 Yogyakarta), Disertasi, Yogyakarta: Program Pascasarjana UMY.

Ki Fudyartanta, 2010, Membangun Kepribadian Watak Bangsa Indonesia yang Harmonis dan Integral, Pengantar ke Wawasan Pendidikan Nasional Indonesia yang Komprehensif, Yogyakarta: Pustaka Pelajar.

Ki Hadjar. Dewantara, 2004, Karya Ki Hadjar Dewantara, Bagian Pertama: Pendidikan,
Yogyakarta: Majelis Luhur Persatuan Taman Siswa.

Koentjaraningrat, 1985, Metode-metode Penelitian Masyarakat, Jakarta: Penerbit, PT Gramedia.

Koesoema A., Doni, 2007, Pendidikan Karakter, Strategi Mendidik Anak di Zaman Global, Jakarta: PT.Grasindo.

Komarudin Hidayat, 2008 , "Oh Pondokku, Ibuku”, Ajip Rosidi (Ed.), Kiai Hamam Dja'far dan Pondok Pabelan:Kesaksian Santri, Kerabat, dan Sahabat, Jakarta: Dunia Pustaka Jaya.

Langgulung, Hasan, 1991, Kreativitas dan Pendidikan Islam Analisis Psikologi dan falsafah, Jakarta: PT. Pustaka Al-Husna.

Langgulung, Hasan, 1992, Asas-Asas Pendidikan Islam, Jakarta: Penerbit Pustaka Al-Husna.

Lexy J, Moloeng, 2005, Metode Penelitian Kualitatif, Bandung: Rosdakarya,

Lickona, Thomas, 2012, Educating For Character, : How Our Schools Can Teach Respect and Responsibility, Terjm. Juma Abdu Wamaungo, Mendidik Untuk Membentuk Karakter (Bagaimana Sekolah Dapat Memberikan Pendidikan tentang Sikap Hormat dan Tanggung Jawab), Jakarta: PT. Remaja Rosdakarya.

Maimunah, Binti, 2009, Landasan Pendidikan, Yogyakarta: Teras.

Muhaimin, dkk., 2002, Paradigma Pendidikan Islam, Upaya Mengefektifkan Pendidikan Agama Islam di Sekolah, Bandung: PT Remaja Rosdakarya.

Mujib, Abdul, 2007, Kepribadian dalam Psikologi Islam, Jakarta: PT Raja Grafindo Persada. 
Mulyasa, 2007, Menjadi guru profesional Menciptakan Pembelajaran Kratif dan Menyenangkan, Bandung: PT Remaja Rosdakarya.

Muhadjir, Noeng, 2002, Metodologi Penelitian Kualitatif, Jakarta: Bumi Akasara. 